\title{
Питання психології
}

УДК 612.821 .34

DOI: $10.33099 / 2617-6858-21-59-1-86-92$

\author{
Грибенюк I. Г. розробник ПЗ \\ https://orcid.org/0000-0003-0700-2896 \\ Темченко Ю. Г. начальник відділу Українського інституту \\ https://orcid.org/0000-0002-3373-986X \\ Грибенюк Г. С. доктор психологічних наук, професор, \\ Черкаський інститут пожежної безпеки \\ імені Героїв Чорнобиля НУЦЗ України \\ https://orcid.org/0000-0002-5053-8744
}

\section{ПРОГНОЗ НА УСПІШНІСТЬ ДІЯЛЬНОСТІ В ЕКСТРЕМАЛЬНИХ УМОВАХ}

Стаття розкриває індивідуальні особливості, які забезпечують успішність професійної діяльності в екстремальних умовах. Концептуалізація змінної «здатність розпізнати сенс та логіку ситуачії», дае змогу обтрунтувати необхідну діагностичну процедуру та отримати дані щодо внутрішніх резервів психіки курсанта. Представлені результати роботи дозволяють з'ясувати окремі взаємозалежності між змістом конщетуальних та операџіональних змінних у дослідженні иієї здатності. Розкрито специфіку моделі готовності курсанта до самосуб'єктних дій.

Ключові слова: успішність; професійна діяльність; екстремальні умови; здатність розпізнавати сенс; параметри саморегуляції; концептуальні змінні; модель готовності.

Вступ.

Збіг простору концептуальних змінних 3 утвореними ними континуумами операціональних змінних $є$ важливим завданням дослідження, яке дає змогу побудувати цілісний простір дослідження, зокрема, щодо прогнозу на успішність діяльності в екстремальних умовах i спроможності курсанта активізувати внутрішні резерви його психіки. Цілісність теоретичної та еміричної моделей створює потужний пояснювальний потенціал, без якого стає неможливим реальне використання бажаного психологічного дискурсу. $€$ необхідність розкрити змінні та їх зв'язки у дослідженні здатності курсанта протидіяти екстремальності та бути успішним за таких умов.

\section{Теоретичне підгрунтя.}

Аналіз результатів досліджень [2], [5], [7], [8] дозволяє зробити висновок про те, що за умовами виникнення й перебігу екстремальних ситуації лежить протидія, особистості екстремальному, подолання нею певних перешкод, деструктивних впливів і небезпек. Увага науковців зосереджена на функціональних проявах фахівця, особливостях екстремальних викликів, проте, утворення самосвідомості, засоби і технологія процесу підготовки як суб' єкта розвитку власної відповідальності та саморегуляції майже не розкриті. Це повною мірою стосується підготовки курсантів до дій за призначенням у сфері цивільного захисту, які готуються на первинні посади.

Нами поставлене завдання з'ясувати методологічні передумови розвитку самоактивності до діяльності в екстремальних умовах як цілісного безперервного процесу. Зокрема, дослідити зв'язки між концептуальними та операціональними змінними, які забезпечують цілісність концептів і діагностичної процедури щодо спроможності курсанта активізувати внутрішні резерви його психіки щоб буте успішним в екстремальних умовах.

\section{Методи дослідження.}

Теоретичний аналіз було проведено за допомогою засобів мови експериментального психологічного дослідження, понять «концептуальної та операціональної змінної», які $€$ засобами упорядкування та приписування числових значень для діагностичної процедури. Логіка такого аналізу починається 3 побудови теоретичної моделі i переходить до емпіричних методів. Описи прогнозу на успішність діяльності в екстремальних умовах переходить в узагальнення, пояснення причинно-наслідкових зв'язків, розробку пояснювальної моделі, в якій присутні елементи передбачення та управління.

Результати і оброворення.

Загальновідомо, що прогноз успішності навчання не дорівнює прогнозу на успішність діяльності у звичайних умовах, а 


\section{Питання психології}

прогноз успішності у звичайних умовах не ідентичний прогнозу на успішність діяльності в екстремальних умовах. Ці положення значно обмежують можливості прямого переносу традиційної діагностики та іiі досвіду в екстремальні умови. Крім того, є специфіка екстремальних умов, зокрема, те, що екстремальні чинники мають комплексний характер дії, а також те, що часто не можливо передбачити, які з них та в якому поєднанні будуть мати перевагу в тій або іншій ситуації. Особливо це стосується психогенних чинників, які, фактично, не піддаються нормуванню.

Тому в дослідженні був використаний інший підхід: поставлено завдання визначити ті індивідуальні особливості, які забезпечують успішність професійної діяльності в екстремальних умовах незалежно від специфіки дії тих або інших несприятливих чинників. Така діяльність ставить людину перед необхідністю оптимальної, а часто й максимальної мобілізації власних потенційних можливостей, вияву високого рівня самоактивності 3 метою подолання перешкод та забезпечення успіху. Здатність фахівця до проявів самоактивності такого високого рівня з'являється як результат розвитку його самоактивності у період попереднього навчання та підготовки. Вдосконалення системи підготовки фахівців стає можливим, коли створюються умови для активізації особистісного потенціалу фахівця, розвитку спроможності курсанта активізувати внутрішні резерви його психіки на основі цілісного уявлення про самоактивність.

Умовно всі дослідження за цією проблематикою можна поділити на три групи: першу складають дослідження самоактивності методологічного плану, другу - дослідження, які стосуються окремих аспектів i етапів розвитку самоактивності, до третьої групи відносять дослідження, де самоактивність розглядається як цілісний безперервний процес [5].

Вивчення розвитку самоактивності іде за кількома напрямками, серед яких, 3'ясування можливостей людини в ситуаціях, де треба оптимально зреагувати на чинники ситуації, передусім, когнітивно. Здатність розпізнати сенс та логіку ситуації значною мірою визначає можливість здолати «екстремальне» та визначає успішність поведінки людини. Саморегулювання в екстремальних ситуаціях і спроможність пізнавати їх сенс $\epsilon$ специфічними видами дій і не синонімічні пізнанню як такому. Психологія їх реальних зв'язків та відношень не достатньо досліджена як теоретична проблема та прикладний напрям в аспекті розробки реальних психолого-педагогічних технологій підготовки, зокрема, рятувальників.

Розглянемо зміст та обсяг поняття «пізнання» в його логічних зв'язках 3 поняттями «навчання» та «учіння», 3 тим щоб з'ясувати мотиваційні та смислові аспекти підготовки до пізнавальної діяльності в екстремальних умовах. та іiі саморегуляції.

Пізнання $є$ «процесом відображення та відтворення дійсності мисленням, зумовлений потребами практики, у взаємодії суб'єкта та об'єкта, результатом якої стає нове знання про світ» $[1,350]$. Підкреслимо деякі психологічні моменти цього філософськи широкого визначення.

Пізнання - це не лише відображення, але і відтворення дійсності, що $\epsilon$ важливим у розумінні активного характеру знання та психіки в цілому. Пізнання розглядається як результат взаємодії, а не просто відбиток об'єкта у суб'єкті, отже передбачає обов'язкову наявність спеціальної активності суб'єкта пізнання. Зрозуміло, що згадані положення $\epsilon$ початковими $\mathrm{y}$ багатозначному філософському баченні проблеми, але, на жаль, у реальній практиці організації процесу пізнання втрачаються або спрощуються, зокрема, у процесі психологічної підготовки фахівців. Так, наприклад, підготовленість до зустрічі 3 екстремальними чинниками починається iз знайомства 3 ними: почуттєвого ознайомлення, перетворення їх у звичні, очікувані. Конкретизуючи цю ідею, інколи зводять справу до демонстрації людині негативних факторів, які викликають внутрішнє неприйняття: неприємні відчуття, важкі переживання, тривожні думки, страх і т.ін. Але у такий спосіб люди отримують однобічне, а значить невірне, уявлення про складні ситуації. Такі ситуації - не лише поле страху, але і поле величі людини, високого професіоналізму, який виявляється у перемозі над будь-якими труднощами. 


\section{Питання психології}

Тому ознайомлення 3 екстремальними ситуаціями повинне обов'язково починатися, поєднуватись і завершуватись демонстрацією всього нормального i позитивного, що реально буває в них. Знайомство $з$ ними здатне змінити реакцію людини i замість негативного дати позитивний ефект.

У наведеному вище визначенні результат пізнання дорівнює мисленню, що наврядчи є правомірним, оскільки реально існують декілька поверхів та ступенів пізнання, які виявляються в екстремальних умовах. $С$ такі з них, що розташовані нижче мислення та зумовлені переважною роллю у діяльності суб'єкта пізнання когнітивних процесів перцепції, пам'яті. В екстремальних умовах існує пізнання, яке піднімається вище рівня мислення, воно змінюе не лише знання суб'єкта про ситуацію, але i самосвідомість людини, іiі ставлення до світу, до себе. Свідомість, як відомо, не зводиться до знань, суми об'єктивних значень та відповідних їм понять. С площина суб' єктивного - «Яобраз», ставлення людини, переживання тощо. У свідомому образі людини екстремальні умови, які пізнаються, можуть бути відокремленими від їх «картинки» [6, 9], між ними з'являється суб'єкт рефлексії. В цьому полягає справжня досконалість пізнання, в тому числі, його довершеність в екстремальних умовах. Коли людина може не лише знати, але і поставитися, оцінити, пережити, усвідомити власні знання. Ця обставина не принижує об'єктивності, адекватності у знаннях людини про екстремальні чинники ситуації, їx перевіреності практикою, але є безумовним реальним дієвим складником.

Отже, результатом пізнання є глибокі, якісні зміни всієї психіки суб'єкта, а не тільки його знань та мислення. Пізнання екстремальної ситуації значить для людини обов'язкові самозміни за всіма психологічними компонентами, серед яких інтелект, наврядчи $є$ психологічно провідним та єдино визначальним.

Якщо у суб'єкта $\epsilon$, наприклад, емоційний досвід долання екстремальних ситуацій, то правомірно вести мову про емоційне пізнання, а не поняттєве. Причому воно не розглядається нами як недосконале або як перешкода «чистому» мисленню. У екстремальних ситуаціях пізнання покликано бути такою ж мірою різним, як i об’єктивна дійсність.

Пізнання логіки розвитку ситуації, насиченої комплексною дією екстремальних чинників: індивідуальною неповторністю небезпек (не відоме планування приміщення, темрява підвалу тощо), стони, постраждалих, вид покалічених, поранених, яких відвозять машини швидкої допомоги, крики дорослих, дітей про допомогу; небезпека вибуху, обрушення конструкцій, де працюють виконавці, страх, що хтось із них постраждає, - все це не може бути зведено до відтворення та відображення їх у мисленні суб'єкта. В екстремальних ситуаціях працюють більш широкі та комплексні психологічні утворення, психіка в цілому, в усій іiі суб'єктивності та суб'єктності. Ми не абстрагуємося у розгляді проявів пізнання в екстремальних умовах від категорії його суб'єктивності та категорії свідомості, вважаємо їх обов'язковими. Така постановка питання щодо пізнання поширюється нами на всі його прояви та їх аспекти в екстремальних умовах, які вивчаються у дослідженні.

Підкреслимо, що на основі розмежування типу, сфери пізнання реально цілісний світогляд людини в екстремальній ситуації доволі чітко проявляє проекції від дії трьох соціальних інститутів: царини віри, наукового (науки) та мистецтва. Зв'язки та перехрещення між ними, безумовно, існують. Наприклад, опора наукова може співіснувати 3 релігійною, відомими $\epsilon$ факти, коли постраждалі, які опинилися під завалами в шахті шукали конкретної можливості допомоги ззовні та одночасно звертались за допомогою до «Бога». Їх стійкість могла бути ідентична релігійній побудові («Допоможе тільки бог, ніхто інший»), одночасно певні настанови такої стійкості $\epsilon$ цілком наукові 3 точки зору обгрунтування можливості самостійного пошуку людиною порятунку.

Очевидно, релігія та мистецтво ближче зараз до живої людини, ніж наукова психологія за успішністю свого впливу на підготовку людини до саморегуляції психіки та зустрічі iï 3 психоемоційними екстремальними чинниками. Безумовно, кінцевого результату там немає: модель регулювання людиною процесу свого пізнання виходить однобокою, фрагментарною, не переконливою. Людина 


\section{Питання психології}

в ній присутня не інакше як у вигляді засобу, ланцюга, який опосередковує та транслює чиюсь емоцію, волю, світогляд, мораль цілепокладання і т. ін. Це може бути віра, яка не вимагає доказів та спростувань, або жива не спростовна за своєю сутністю феноменологія, але не більше того, які не дають необхідного для пізнання та дійсно глибинного розуміння людиною сенсу екстремальної взаємодії та необхідного прогнозування.

Вищезазначені світоглядні компоненти, безумовно, не схожі, але головна сутнісна їх різниця пролягає глибше та є принциповою: це сформовані моделі світу, та самого суб'єкта, його саморегуляції та їх взаємодії у процесі пізнання в цілому та екстремальної ситуації, зокрема.

Модель процесу пізнання $\epsilon$ філософською проблемою, але i психологічною також. У власній моделі пізнання екстремальної ситуації суб'єктом ми не хотіли втратити фактичного суб'єкта, який у процесі пізнання $\epsilon$ необхідним його атрибутом та специфікою предмету дослідження.

Така мета вимагає побудувати методологію емпіричного вивчення таким чином, щоб «стихія... души» [4], яка, без сумніву, $є$ суттєвим чинником екстремальної ситуації, не залишила дослідження та не загубити «спочатку душу, а потім свідомість та розум» [3].

Наблизити модель пізнання як відображення до реальної живої людини та відтворити у дослідженні багатофакторну іiі сутність в екстремальних умовах допоможе виділення та розгляд окремих характеристик суб'єкта, зокрема, світоглядних.

Ми не ставимо знак рівняння між поняттями «духовності» та «набожності», як передумовами готовності та гарантією спроможності людини до успішних дій в екстремальних умовах, рівно як не відносимо протилежну їм пару: «гроші» та «ідеал» до синонімів здолання екстремального. У будь-якій поляризації загублюється дещо головне, для чого створені всі соціальні інститути суспільства. Цим головним $\epsilon$ реальна людина, яка $з$ йй одній відомих міркувань, а значить і заради чогось, хоче пізнати екстремальну природу різних ситуацій, у нерозривній єдності 3 якими вона існує, зреалізувати себе саме в них; підтвердженням тому $€$ факти щорічних змін, які вносяться до книги рекордів Гіннеса та вражають природою екстремального здоланого людиною.

Звідси наша переконаність, що провідними характеристиками моделі особистості, яка спроможна успішно діяти в екстремальних умовах, $є$ взаємозалежність між змістом морально-релевантних ціннісних орієнтацій особистості i iï психологічною та фаховою готовністю до діяльності в екстремальних умовах.

Крім самих довершених ціннісних характеристик людині потрібні когнітивні можливості по виокремленню закономірностей екстремальної ситуації, 3'ясуванню механізмів того, що відбувається (його причин, прогнозу, змін, ймовірнісної моделі ситуації i т.ін.), i, нарешті, накопичення власного досвіду екстремальної взаємодії, його привласнення та «раціоналізація» у вигляді можливих рекомендацій собі до практики самоуправління, регулювання, цілеспрямованого формування i т. ін. та впровадження його у власну професійну практику.

Провідними утвореннями у структурі особистості, що забезпечують належний рівень такої самоактивності та успішність діяльності за екстремальних умов ми вважаємо наступні: сформованість адекватних специфіці діяльності в екстремальних умовах когнітивних умінь та навичок, а також здатність до саморегуляції поведінки та діяльності як бази самосуб'єктної дії.

Простіше за все покладатись на досвід розрізнених пережитих людиною фактів та чужі поради, таке знання $\epsilon$ мінливим, залежним від параметрів ситуації, а тому менш достовірним; набагато складніше для людини зуміти виділити, систематизувати та передбачити події на основі набутого емпіричного знання. Практична значущість емпіричного знання, отриманого людиною, забезпечується значними аналітикооціночними зусиллями по виділенню його прикладної спроможності.

Виокремленні характеристики моделі пізнання системно пов'язані з особливими формами організації процесу пізнання методологією та формою організації навчання і виховання в суб'єкта в межах його професійної підготовки.

Методологічне

обгрунтування 


\section{Питання психології}

теоретичних

сформулювати

необхідного

використання

методів, адекватних об'єкту, предмету, меті та завданням дослідження, а також віковим особливостям контингенту досліджуваних.

Оцінювані психологічні параметри саморегуляції, як операціональні змінні, мають доволі складну, пов'язану, але не однозначну в різних компонентах моделі готовності до самосуб' єктної дії картину. Вона структурно-різнотипна, поліморфна, складається 3 трьох прошарків властивостей суб'єкта саморегуляції:

базовий макрорівень - наскрізноситуативні властивості суб'єкта саморегуляції досягати поставленої мети протягом років навчання, система яких змодельована за показниками предметнопрактичного плану. Це реалізовані курсантом особистісні стратегіï саморегуляції у сферах його життедіяльності: навчальній, міжособистісної взаємодії, включеності соціального «Я» у малу професійну групу, як оцінений в балах досвід міри успішності реалізації (незначної, звичайної, успішної та найбільш успішної), який характеризує суб'єкта на рівні мотивів-цілей вибору мети саморегуляції та його готовності до самосуб'єктної регуляції (дій);

мезорівень - відносно узагальнені властивості-навички суб'єкта саморегуляції, які відносяться до широкого класу ситуацій, що змодельовані за показниками оцінних ставлень спрямованості самосвідомості, а також ієрархічної системи мотивів регуляції діяльності та іï стильових особливостей, який характеризує суб'єкта на рівні мотивівобгрунтувань вибору шляхів, засобів, способів реалізації мети саморегуляції та його готовності до самосуб'єктної регуляції (дій);

мікрорівень - локально-ситуативні властивості-стратегії суб'єкта, які задають певні сценарії поведінки майбутнього фахівця у конкретних професійних ситуаціях саморегуляції та характеризують суб'єкта на рівні мотивів-цілей вибору ним мети саморегуляції та мотивів-обгрунтувань i його комплексну готовність до самосуб'єктної регуляції (дій). Зазначена спроможність суб'єкта складається із усвідомлення ним напружених, екстремальних моментів професійної діяльності, вміння регулювати їх під час розв'язання завдань виявлення, сприйняття сенсу ситуації та його трансформації, за підсистемами: екстраполяції подій, прогностичною; інтерполяції попередніх подій, зворотнозв'язковою; екстраполяції подій через їх синтез; інтерполяції подій, стабілізаційною; витривалості; компонентою трансформації сенсу, результативність «ввімкнення» яких оцінена балами.

3 точки зору мотивації, що в них переважає, операціональні змінні характеризують: 1) обрані пріоритети у навчанні, міжособистісній взаємодії, включеності у малу професійну групу; 2) вміння ситуативно регулювати напружені, екстремальні моменти професійної діяльності під час розв'язання завдань інтерпретації сенсу; 3) суб'єктивну оцінку спрямування самосвідомості та структур регуляції діяльності - сенс яких цілком узгоджується із психологічним змістом технології підготовки майбутнього фахівця до дій в екстремальних умовах.

В результаті побудови концептуальних та операціональних змінних розкривається суб' єктнй аспект індивідуальної саморегуляції психіки курсантом.

Діагностичне забезпечення емпіричного дослідження може здійснюватись за допомогою різних методик, зокрема, таких: невербального тесту Р. Б. Кеттела, опитувальника Р. Амтхауера, вербального тесту творчих здібностей, особистісного орієнтаційного опитувальнику В. Смекала, М. Кучери, опитувальника визначення рівня суб' єктивного контролю Дж. Роттера, методики ціннісних орієнтацій М. Рокича, тощо.

\section{Висновки.}

Теоретико-методологічні та діагностичні питання, які розкриті вище, мають цілком певне прикладне, психологопедагогічне використання. Вони входять до практичного завдання надзвичайної значущості, актуальності та багатофакторності: $\quad$ вдосконалення психолого-педагогічної підготовленості майбутніх фахівців та їх керівників у системі професійної підготовки.

Таким чином, виявлені особливості компоненти «успішність діяльності в екстремальних умовах» дозволяють 


\section{Питання психології}

розробити та обгрунтувати теоретичну та емпіричну моделі спроможності курсанта активізувати внутрішні резерви психіки в умоваз навчально-професійної діяльшності та забезпечують належну готовність до самосубєктного регулювання.
Перспективи подальших досліджень пов'язані 3 необхідністю розгортати отримані моделі самосуб'єктної регуляції у практиках психологічних досліджень, обстежень, допомог в цій та інших екстремальних професіях.

\section{Список використаних джерел}

1. Білодід І. К. Словник української мови: в 11 т. / Білодід І. К. - Київ: Наукова думка, 1980. - 530 с. - (АН УРСР. Інститут мовознавства).

2. Боришевский М. Й. Розвиток саморегуляції поведінки школярів : автореф. дис. на здобуття наук. ступеня докт. псих. наук : спец. 19.00.07 «педагогічна та вікова психологія» / Боришевский Мирослав Йосипович - Інститут психології НАПН ім. Г. С. Костюка, 1992. - 77 с.

3. Боришевський М. Й. Психологія самоактивності учнів у виховному процесі: навчальнометодичний посібник / Мирослав Йосипович Боришевський. - К.: ІЗМН, 1998. - 192 с.

4. Гальперин П. Я. Вступ до психології / Петро Якович Гальперин. - Москва, 1985. - 193 с.

5. Грибенюк Г. С. Психологічні основи становлення саморегуляції у навчально-професійній діяльності майбутніх рятівників : дис. докт. псих. наук : 19.00.07 - «педагогічна та вікова психологія» / Грибенюк Геннадій Сергійович - Інститут психології ім. Г. С. Костюка АПН України, 2007. -380 с.

6. Леонт'єв О. М. Проблеми розвитку психіки / Олексій Миколайович Леонт'єв. - М.: МГУ, 1981. $-584 \mathrm{c}$.

7. Миронець С. М. Негативні психічні стани та реакції у працівників аварійно-рятувальних підрозділів МНС України в умовах надзвичайної ситуації : автореф. дис. на здобуття наук. ступеня канд. психол. наук : спец. 19.00.09 «Психологія діяльності в особливих умовах» / С. М. Миронець. Харків, 2007. - $21 \mathrm{C}$.

8. Приходько Ю. О. Психологічні чинники успішності професійної діяльності пожежнихрятувальників МНС України : дис. ... кандидата психологічних наук: 19.00 .09 - «Психологія діяльності в особливих умовах» / Приходько Юрій Олександрович. - К., 2008. - 230 с.

9. Рубінштейн С. Л. Основи загальної психології / Сергій Леонідович Рубінштейн. - СПб.: Пітер, 2001. $-720 \mathrm{c}$.

\section{References}

1. Bilodid I. K. (1980) Slovnyk ukrainskoi movy: v 11 t. [Dictionary of the Ukrainian language: in 11 volumes]. Kyiv: Naukova dumka, 125 (in Ukrainian).

2. Boryshevskyi M. Y. (1992) Razvytye samorehuliatsyy povedenyia shkolnykov [Development of selfregulation of schoolchildren's behavior] (Abstract of D.Sc. thesis). Kyiv (in Ukrainian).

3. Boryshevskyi M. Y. (1998). Psykholohiia samoaktyvnosti uchniv u vykhovnomu protsesi: navchalnometodychnyi posibnyk [Psychology of self-activity of students in the educational process: a textbook] (Abstract of D.Sc. thesis). Kyiv: IZMN.19 (in Ukrainian).

4. Halperyn P. Ya. (1985). Vstup do psykholohii [Introduction to psychology]. Moskva (in Russia).

5. Hrybeniuk H. S. (2007). Psykholohichni osnovy stanovlennia samorehuliatsii u navchalno-profesiinii diialnosti maibutnikh riativnykiv [Psychological bases of formation of self-regulation in educational and professional activity of future rescuers] (Abstract of D.Sc. thesis). Kyiv: Instytut psykholohii im. H. S. Kostiuka APN Ukrainy (in Ukrainian).

6. Leontiev O. M. (1981). Problemy rozvytku psykhiky [Problems of mental development]. Moskva: MHU (in Russia).

7. Myronets S. M. (2007). Nehatyvni psykhichni stany ta reaktsii u pratsivnykiv avariino-riatuvalnykh pidrozdiliv MNS Ukrainy $\mathrm{v}$ umovakh nadzvychainoi sytuatsii [Negative mental states and reactions of employees of emergency rescue units of the Ministry of Emergencies of Ukraine in emergency situations] (Abstract of $\mathrm{PhD}$ thesis). Kharkiv (in Ukrainian).

8. Prykhodko Yu. O. (2008). Psykholohichni chynnyky uspishnosti profesiinoi diialnosti pozhezhnykhriatuvalnykiv MNS Ukrainy [Psychological factors of success of professional activity of firefighters-rescuers of the Ministry of Emergencies of Ukraine] (Abstract of PhD thesis). Kyiv (in Ukrainian).

9. Rubinshtein S. L. (2001). Osnovy zahalnoi psykholohii [Fundamentals of general psychology]. SPb.: Piter, (in Russia). 


\section{Питання психології}

\section{Резюме}

Грибенюк И. разработчик ПО

Темченко Ю. начальник отдела Украинського института

Грибенюк Г. доктор психологических наук, профессор,

Черкасский институт пожарной безопасности

имени Героев Чернобыля НУГЗ Украины

\section{ПРОГНОЗ УСПЕШНОСТИ ДЕЯТЕЛЬНОСТИ В ЭКСТРЕМАЛЬНЫХ УСЛОВИЯХ}

Статья раскрывает индивидуальные особенности, которые обеспечивают успешность профессиональной деятельности в экстремальных условиях. Концептуализация переменной «способность распознать смысл и логику ситуаџии», позволяет обосновать необходимую диагностическую процедуру и получить данные о внутренних резервах психики курсанта. Представлены результаты работы позволяют выяснить отдельные взаимозависимости между содержанием концетуальних и операциональных переменных в исследовании этой способности. Раскрыта спеиифика модели готовности курсанта к самосубъектнми действиям.

Ключевые слова: успешность; профессиональная деятельность; экстремальные условия; способность распознавать смисл; параметры саморегуляиии; концептуальные переменные; модель готовности.

\section{Summary \\ Hrybeniuk I. software developer \\ Temchenko Yu. head of the department of the Ukrainian Institute \\ Hrybeniuk $\boldsymbol{H}$. doctor of psychological sciences, Professor, \\ Cherkasy Institute of Fire Safety named after Chornobyl Heroes \\ of National University of Civil Defence of Ukraine}

FORECAST FOR SUCCESSFUL ACTIVITY IN EXTREME CONDITIONS

Introduction. The coincidence of the space of conceptual variables with the continua of operational variables formed by them is an important task of the study, which allows to build a holistic space of research, in particular, to predict the success of activities in extreme conditions and the cadet's ability to activate internal reserves. The integrity of theoretical and emirical models creates a powerful explanatory potential, without which the real use of the desired psychological discourse becomes impossible. There is a need to uncover variables and their relationships in the study of a cadet's ability to resist extremes and be successful in such conditions.

Purpose. Our task is to clarify the methodological prerequisites for the development of self-activity to work in extreme conditions as a holistic continuous process. In particular, to explore the relationships between conceptual and operational variables that ensure the integrity of concepts and the diagnostic procedure for a cadet's ability to activate the internal reserves of his psyche to be successful in extreme conditions..

Methods. Theoretical analysis was performed using the language of experimental psychological research, the concepts of "conceptual and operational variables", which are a means of ordering and assigning numerical values for the diagnostic procedure. The logic of such an analysis begins with the construction of a theoretical model and moves on to empirical methods. Descriptions of the forecast for the success of activities in extreme conditions turns into generalization, explanation of causation, development of an explanatory model, which contains elements of prediction and management.

Originality. The scientific novelty of the article is the development of systematic ideas about the conceptual means of experimental psychological research language, in particular, the concept of " ability to recognize the meaning and logic of the situation " as a unit of research. Identifying features of this variable as a means of ordering, classifying, and assigning numerical values in the study of rescuers' self-regulation.

Conclusion. Thus, the revealed features of the component " the ability to recognize the meaning of the situation " allow to develop and substantiate theoretical and empirical models of formation of future rescuers' self-regulation in conditions of educational and professional activity, which ensure proper readiness for selfsubjective regulation.

Key words: success; professional activity; extreme conditions; ability to recognize meaning; parameters of self-regulation; conceptual variables; model of readiness.

Автори заявляють про відсугність конфлікту інтересів.

Recelved/Поступила: 05.02. 21. 